\title{
Monetary Fines in EU Mergers: In Need for More Regulation $^{*}$
}

\author{
Nora Memeti**
}

\begin{abstract}
Monetary fines represent an important instrument to address violations of Competition Law. The European Commission (EC) and the EU Courts have been primarily engaged in imposing fines in cases of breach of the first pillar, and have rarely dealt with cases of abuse based on the fining guidelines issued in accordance with Article 23(2) of Regulation 1/2003. Compared to the first two pillars, mergers have not received similar scholarly attention. ${ }^{1} 2$ Since 2017, the EC has expressed a growing interest in investigating and imposing significant fines to mergers and acquisitions in breach of procedural matters. Therefore this article addresses the application of Article 14 of the European Union Merger Regulation (EUMR) in imposing fines to mergers with European Union (EU) dimension.
\end{abstract}

The EC decisions and EU Courts' judgments related to fines on mergers in breach of procedural matters are discussed in four specific sections.

The first section analyses article 14(1) of the EUMR, which empowers the EC to impose a fine of up to $1 \%$ of the total turnover in the preceding business year on undertakings for breach of procedural matters, including, among others, for providing incorrect or misleading information. This section will address the case of Facebook as the first case in which the EC imposed fines based on the new EUMR. In this case, although the undertakings mislead the EC, based on the offered cooperation, the Authority decided to reduce the fine. In addition, it is also important to address the legal basis applied by the EC in accepting the offered cooperation as a mitigating factor and whether this may develop into a guiding "precedent" in the future.

\footnotetext{
* Associate Professor of Law, Commercial Law Department, KILAW, Doha, Kuwait.

${ }^{1}$ The transaction has a Union dimension within the meaning of Article 1(2) of the EUMR.

${ }^{2}$ Damien Geradin and Katarzyna Sadrak, "The EU competition law fining system: A quantitative review of the Commission Decisions between 2000 and 2017", TILEC Discussion Paper No. 20172018 (2017).
} 
The second section deals with five cases of violations of articles 4(1) and 7(1) EUMR related to fines prescribed in article 14(2) EUMR. With regards to four of them, judgments of EU Courts and decisions of the EC and National Competition Authority (NCA) are analysed. The fifth case, the one on Ernst and Young, provides for the first preliminary ruling on the notion of "gun-jumping".

The third section deals with Article 14(3) and the fining methods on mergers. By reviewing each of these five cases, it is important to address factors taken into consideration when imposing fines. An obvious deficiency is the absence of a legal basis, regardless of whether manifested in hard or soft law. Here it is relevant to inquire in what manner the EC imposes fines and why it occasionally mirrors the fining guidelines applicable to other pillars of EU Competition Law. The last point to be addressed is the one of policy and the need to balance EC discretional powers and relevant legal principles such as legal certainty, equal treatment, transparency, and consistency. ${ }^{3}$ The fourth section provides for concluding remarks.

KEYWORDS: EUMR, fines, breach of procedural matters, gun-jumping.

\section{The case where misleading information was considered a mitigating factor}

Under Article 14(1)(a)(b) EUMR, ${ }^{4}$ the EC can impose on undertakings, by decision, fines not exceeding $1 \%$ of the total turnover in the preceding business year for intentional or negligent conduct when providing incorrect or misleading information. ${ }^{5}$ In correlation with Article 4 EUMR, undertakings have the duty to provide correct information during the notification process and other submissions. ${ }^{6}$ It is essential for the EC to review mergers and acquisitions on time and effectively, searching for misleading

\footnotetext{
${ }^{3}$ See Frederic Marty and Mehdi Mezaguer, "Negotiated procedures in EU competition law", in Encyclopedia of Law and Economics, ed. Alain Marciano, Giovanni Battista Ramello (New York: Springer, 2018).

${ }^{4}$ Council Regulation (EC) No. 139/2004 of 20 January 2004 on the control of concentrations between undertakings (the EC Merger Regulation), OJ L 24/1, 29 January 2004.

${ }^{5}$ Paragraph 1 of Article 14 states: "EC by decision impose on the persons referred to in Article 3(1) b, undertakings or associations of undertakings, fines not exceeding $1 \%$ of the aggregate turnover of the undertaking or association of undertakings concerned within the meaning of Article 5 where, intentionally or negligently: (a) they supply incorrect or misleading information in a submission, certification, notification or supplement thereto, pursuant to Article 4, Article 10(5) or Article 22(3)".

${ }^{6}$ This article specifies the details of notification prior to implementation and subsequently following the conclusion of an agreement.
} 
and incorrect information. ${ }^{7}$ It is the notifying parties' duty to make a full and honest disclosure of the relevant facts and circumstances to the EC. ${ }^{8}$ Facebook ${ }^{9}$ is the very first case fined based on the EUMR for providing incorrect or misleading information. ${ }^{10}$ In the case of Facebook's acquisition of Whatsapp, the EC imposed two fines on the acquirer for providing incorrect and misleading information in both the notification form and in the additional request for information by the EC. Only the acquirer has the duty to notify the concentration, therefore it was understandable that only Facebook was liable. ${ }^{11}$ However, surprisingly enough, the request for information by the EC was addressed only to Facebook and did not include Whatsapp although both companies should have been addressed at that stage of the proceedings. The registered turnover in 2016 was $€ 28$ billion and, after reducing the fine from $1 \%$ to half, the undertaking was due to pay $€ 55$ million for providing false information in the notification form and $€ 55$ million for providing the same information in the subsequent request, each equal to $0.22 \%$. The EC concluded that an overall fine of $€ 110$ million was proportionate and a deterrent as well. ${ }^{12}$

\section{Evolution of fines}

To ensure effective control, undertakings must give prior notification of concentrations with a Community dimension following the conclusion of the agreement, the announcement of the public bid or the acquisition of a controlling interest. ${ }^{13}$ By doing so, the EU legislator drafted the European merger control to be able to prevent undertakings from implementing such transactions before taking a final decision, with a view to avoid any

\footnotetext{
${ }^{7}$ Article 4(1) of EUMR. The previous notification deadline of 7 days after reaching a merger agreement was repealed with the 2004 reforms.

${ }^{8}$ See Recital 5 of the Regulation implementing EUMR (Regulation 802/2004).

${ }^{9}$ Commission Decision of 17 May 2017, imposing fines under Article 14(1) of Council Regulation (EC) No. 139/2004 for the supply by an undertaking of incorrect or misleading information (Case No. M.8228 - Facebook/Whatsapp).

${ }^{10}$ In the past, decisions related to non-correct or misleading information were adopted under the old ECMR with different fine-setting. Council Regulation (EEC) 4064/89 (OJ 1989 L395/1, 30.12.1989), see also Commission Decision of 27 May 1998, relating to a proceeding to Council Regulation (EEC) No. 4064/89 (Case No. IV.M993 - Bertelsmann/Kirch/Premiere) (1999/153/EC), May 27, 1998 [1999] O.J. L53/1.

${ }^{11}$ Article 4(2) of the EUMR.

${ }^{12}$ The two ongoing cases concerning the alleged provision of incorrect or misleading information relate to Merck and Sigma-Aldrich and Ge and LM Wind.

${ }^{13}$ Recital 34 of the EUMR.
} 
permanent and irreparable damage to effective competition. A merger control is not about the protection of shareholders' benefits, it is carried out in the public interest. ${ }^{14}$ Article 14(2) allows the EC to impose fines on an undertaking not exceeding $10 \%$ of the total turnover in the preceding business year when, intentionally or negligently, it failed to notify a concentration prior to its implementation, in breach of Article $4(1)^{15}$ and/or 7(1) EUMR. ${ }^{16}$

\subsection{There was a time when fines were symbolic}

Previously, fines were imposed based on the former Regulation. ${ }^{17}$ Compared to other jurisdictions, in particular the US, the recent proceedings within the EU are also considered novel. ${ }^{18}$ At the EU level, the case of Samsung was the first case in which a fine of $€ 33,000$ was imposed for non-notification. ${ }^{19}$ In this case, the EC established that these fines were to be imposed in both intentional and negligent circumstances. ${ }^{20}$ The EC

\footnotetext{
${ }^{14}$ Ioannis Kokkoris, and Howard Shelanski, EU Merger Control: A Legal and Economic Analysis (Oxford: Oxford University Press, 2014), 10.

${ }^{15}$ Article 4(1), "Concentrations with a Community dimension defined in this Regulation shall be notified to the EC prior to their implementation and following the conclusion of the agreement, the announcement of the public bid, or the acquisition of a controlling interest".

${ }^{16}$ Article 7(1), "A concentration with a Community dimension as defined in Article 1, or which is to be examined by the EC pursuant to Article 4(5), shall not be implemented either before its notification or until it has been declared compatible with the common market pursuant to a decision under Articles 6(1)(b), 8(1) or 8(2), or on the basis of a presumption according to Article 10(6)" ${ }^{17}$ Council Regulation (EEC) 4064/89 (OJ 1989 L395/1, 30.12.1989), as amended by Council Regulation (EC) 1310/97 (OJ 1997 L180/1, 9.7.1997; corrigendum OJ 1998 L40/17, 13.2.1998). Based on the former Regulation, the EC had already proceeded against other undertakings and imposed fines on them for breach of Article 7(1) of the Merger Regulation; see Samsung/AST, AP Moller and Electrabel/CNR. The COM has also adopted a number of other decisions on the basis of Article 14 of EUMR; See Decisions in Cases No. IV/M.1543 Sanofi/Synthelabo (1999); COMP/M.1608 KLM/ Martinair (1999); M.1610 Deutsche Post/Trans-O-Flex (2001); CONMP/M.1634 Mitsubishi Heavy Industries (2000); COMP/M.2624 BP/Erdölchemie (2002); COMP/M.3255 Tetra Laval/Sidel (2004).

${ }^{18}$ Morse, M. Howard. "Mergers and acquisitions: Antitrust limitations on conduct before closing", The Business Lawyer 57, no. 4 (2002): 1463-1486; Ilene Knable Gotts, The Merger Review Process: A Step-by-Step Guide to US and Foreign Merger Review, $3^{\text {rd }}$ Edition (United States of America: ABA Publishing, 2006); See also Peter Alexiadis, Elsa Sependa, and Laura Vlachos, "Merger control: 'Around the world in 80 days: Management of the merger review process of global deals"', Business Law International 19, no. 3 (2018), 240.

${ }^{19}$ Commission Decision of 26 May 1997, Samsung/Ast (Case No. IV/M. 920). See also, D. L. D. Bruno, and F. V. B. Morselli, "Clarifying gun-jumping through guidelines: The Brazilian experience", Journal of European Competition Law \& Practice (2015): 130-134.

${ }^{20}$ Commission Decision of 18 February 1998, imposing fines for failing to notify and for putting into effect a concentration in breach of Article 4(1) and Article 7(1) of Council Regulation (EEC) No. 4064/89 (Case No. IV/M.920 Samsung/Ast) (paragraph 10).
} 
imposed a fine on Samsung for notifying the acquisition of AST 14 months after the transaction was closed. The second case was Moller, ${ }^{21}$ fined with $€ 219,000$ for notifying three reportable concentrations only two years after the merger. These were the first cases in which the EC declared an infringement of the standstill obligation based on the former Merger Regulation. ${ }^{22}$ It is obvious that the amounts of these fines may be considered symbolic from today's perspective.

After a decade of silence, dramatic developments took place with the EC adopting decisions to impose fines on Electrabe ${ }^{23}$ and Marine Harvest ${ }^{24}$ in the amount of $€ 20$ million in both cases, for breach of articles 4(1) and 7(1) EUMR.

\subsection{The case of Electrabel: prima facie no competition concern}

In the Electrabel case, the EC, and the Courts ruled that Article 7(1) EUMR on the standstill obligation was violated. ${ }^{25}$ During the period between June and December 2003, Electrabel, a Belgian energy undertaking, increased its shareholding in the French electricity undertaking Compagnie Nationale du Rhône (CNR) from 17.86\% to 49.95\% of CNR's capital and $47.92 \%$ of its voting rights. At that time the acquisition was not notified to the EC. In 2007, Electrabel requested the EC for an opinion as to whether they had exercised de facto control over CNR. In the beginning of 2008, Electrabel formally notified the transaction to the EC and was unconditionally cleared. Whether the acquirer controlled CNR was not addressed at that time. Taking into consideration several factors, in particular the share of capital consisting of $49.95 \%$ and the voting rights consisting of $47.92 \%$, the EC concluded that Electrabel had acquired de facto control over CNR since December 2003, thus triggering a EUMR filing requirement. As a result, a fine of $€ 20$ million was imposed to the

\footnotetext{
${ }^{21}$ Commission Decision of 10 February 1999, imposing fines for failing to notify and for putting into effect three concentrations in breach of Article 4 and Article 7(1) of Council Regulation (EEC) No. 4069/89 (Case No. IV/M.969 AP Moller).

${ }^{22}$ Council Regulation (EEC) 4064/89 (OJ 1989 L395/1, 30.12.1989), as amended by Council Regulation (EC) 1310/97 (OJ 1997 L180/1, 9.7.1997; corrigendum OJ 1998 L40/17, 13.2.1998).

${ }^{23}$ Commission Decision of 10 June 2009, imposing a fine for putting into effect a concentration in breach of Article 7(1) of Council Regulation (EEC) No. 4064/89 (Case No. Comp/M. 4994 Electrabel/Compagnie Nationale du Rhone), see infra note 39.

${ }^{24}$ Commission Decision of 30 September 2013, pursuant to Article 6(1)(b) in conjunction with Article 6(2) of Council Regulation No. 139/2004 (Case No. COMP/M.6850, Marine Harvest/ Morpol).

${ }^{25}$ Judgment of 3 July 2014, Electrabel v. EC, C-84/13 P, EU:C:2014:2040.
} 
acquirer. This fine was upheld by the General Court ruling that Electrabel had violated the principle of standstill obligation as it held an effective majority at shareholder meetings and a majority over the board of directors since December 2003. Although the undertaking argued that this was only a procedural violation, this argument was rejected; stressing out that a failure to file a reportable transaction was a serious violation of EU competition law. In this case, the Regulation concerning limitation periods for proceedings was applied. ${ }^{26}$ This Regulation provides a clear distinction between infringement of a procedural nature related to the notification of obligation with limitation periods of three years and infringements related to substantial changes in the conditions of competition with limitation periods of five years. Considering that the infringements of Article 7(1) are subject to a five-year limitation period and they are permanent since the limitation period that starts only at the end of the infringements, the General Court upheld the EC decision. ${ }^{27}$ Lastly, in 2014, the ECJ rejected the case in its entirety, since Electrabel was raising new arguments not raised in the General Court before. ${ }^{28}$

\subsection{Marine Harvest: establishing principles}

While the Marine Harvest (Marine) case is pending before the ECJ, this article analyses the EC decision and the General Court's Judgment. The decision, and in particular the Court's review, is a thought provoking one to be considered as a pattern of development, since it clarifies the standstill obligation in bids and creeping takeovers. The second reason is that this is the first case fined for effectively implementing a transaction before notifying it and prior to getting the approval, based on articles 4(1) and 7(1) EUMR.

Marine acquired his competitor Morpol, a Norwegian undertaking active in farming and processing salmon. In 2012 (12 December), Marine entered into a share purchase agreement (SPA) with Morpol. Through SPA, Marine acquired $48.5 \%$ of Morpol's market share capital. The closing of the acquisition took place on December 18, and Morpol did not notify the

\footnotetext{
${ }^{26}$ Regulation (EEC) No. 2988/74 of the Council of 26 November 1974 concerning limitations periods in proceedings and the enforcement of sanctions under the rules of EEC related to transport and Competition.

${ }^{27}$ Judgment of 12 December 2012, Electrabel v. EC, T-332/09, EU:T:2012:672, paragraph 212.

${ }^{28}$ Judgment of 3 July 2014, Electrabel v. EC, C-84/13 P, EU:C:2014:2040.
} 
acquisition of more than $1 / 3$ of the shares of an undertaking listed in the Oslo stock exchange, which was its duty according to Norwegian law. ${ }^{29}$

Only a year later, in 2013 (15 January), Marine made a mandatory public bid under the Norwegian Securities Trading Act for the remaining shares in Morpol. Following the completion of this mandatory bid, two months later, Marine possessed $87.1 \%$ of the shares in Morpol, and consequently Morpol was de-listed from the Oslo Stock Exchange. Marine formally notified the transaction to the EC on 9 August 2013. The undertaking informed the EC that it would not exercise any voting rights or control over Morpol pursuant to the exception set forth by Article 7(2) EUMR. In these circumstances, the EC raised concerns that the transaction may significantly reduce competition in the market for the farming and processing of Scottish salmon. Therefore, on 30 September 2013, the EC conditionally cleared Marine's acquisition of Morpol. Finally, in 2014 (March), the authority issued a statement of objections to Marine alleging that the undertaking had already acquired de facto control over Morpol as a result of the completion of the December 2012 acquisition. ${ }^{30}$ During the same year (July), the EC adopted an infringement decision finding that Marine had breached both the notification and the standstill obligation and imposed two fines totaling €20 million (each $€ 10$ million). The Authority considered that the acquisition of the 48.5\% shareholding in December 2012 conferred de facto sole control of Marine over Morpol, regardless of Marine trying to demonstrate that it had been abstaining from exercising its voting rights in Morpol prior to obtaining clearance of the transaction. Although Marine argued that it could benefit from the exception for the so-called "creeping bids" under Article 7(2) EUMR, the Authority underlined that this article applied to acquisitions of control by means of acquisition of shares from "various sellers" and Marine had acquired its shares in Morpol from a single seller only. ${ }^{31}$ The General Court confirmed the legality of the fine imposed by the EC on Marine..$^{32}$ Based on the Marine appeal to the General Court, a valuable judgment for undertakings in the market was upheld. The judicial review brought clarity on a number of important principles related to the application of procedural

\footnotetext{
${ }^{29}$ European Commission, "Mergers: Commission fines Marine Harvest $€ 20$ million for taking control of Morpol without prior EU merger clearance", 23 July 2014, under "Press Releases", http:// europa.eu/rapid/press-release_IP-14-862_en.htm.

${ }^{30} \mathrm{Ibid}$.

${ }^{31}$ Case No. COMP/M.6850, Marine Harvest/Morpol, paragraph 7.

${ }^{32}$ Judgment of 26 October 2017, Marine Harvest ASA v. EC, T-704/14, EU:T:2017:753.
} 
aspects of the EUMR not discussed previously in this context. It included the principles of ne bis in idem and equal treatment, ${ }^{33}$ and further clarified the concepts of negligence, single concentration, and creeping bids. The Court in this case strictly defined the principle of negligence by stating that the undertaking could not be unaware of the anti-competitive nature of its conduct. ${ }^{34}$ In particular, it was emphasised that it may have been easy for Marine to foresee that the acquisition of a $48.5 \%$ shareholding in Morpol would confer de facto sole control over the latter undertaking, as evidenced by Marine's stock exchange announcement in December 2012 that the transaction would trigger an EU filing. ${ }^{35}$ The Court held that the experience of an undertaking in the field of concentrations and in notification procedures is a relevant factor in assessing negligence, and that particular diligence ${ }^{36} \mathrm{had}$ to be expected from a large European undertaking which had already been fined (although at the national level) for the early implementation of a concentration. ${ }^{37}$ The General Court concluded that Marine acted negligently by interpreting Article 7(2) in a way that was not consistent with its wording, the EC's previous practice in taking decisions, the case law of the EU Courts, and the EC's statements, albeit in an obiter dictum, in previous merger decisions. ${ }^{38}$

With regard to the principle of ne bis in idem, ${ }^{39}$ which according to Marine was violated by the EC, ${ }^{40}$ the General Court took the position that

\footnotetext{
${ }^{33}$ Judgment of 12 December 2012, Electrabel v. EC, T-332/09, EU:T:2012:672.

${ }^{34}$ Judgment of 26 October 2017, Marine Harvest ASA v. EC, T-704/14, EU:T:2017:753, paragraphs 237-238.

${ }^{35}$ Judgment of 26 October 2017, Marine Harvest ASA v. EC, T-704/14, EU:T:2017:753, paragraphs 243-244.

${ }^{36}$ Article 14 EUMR allows the EC to impose fines for breaches of the EUMR only when such breach is carried out with intent or as a result of negligence. See also Emanuel Gomes, Duncan N. Angwin, Yaakov Weber, and Shlomo Yedidia Tarba, "Critical success factors through the mergers and acquisitions process: Revealing pre-and post -M\&A connections for improved performance", Thunder bird International Business Review 55, no. 1 (2013): 13-35. Check also Peter Howson, Due diligence: The critical stage in mergers and acquisitions (United Kingdom: Routledge, 2017).

${ }^{37}$ Judgment of 26 October 2017, Marine Harvest ASA v. EC, T-704/14, EU:T:2017:753, paragraphs $257-258$.

${ }^{38}$ Commission Decision of 21 September 2007, Merger Procedure Article 6(1)(b) Decision in Conjunction with 6(2) (Case. COMP/M.4730 - Yara/KemiraGrowHow), paragraph 259.

${ }^{39}$ Bas Van Bockel, The Ne Bis in Idem Principle in EU Law, Vol. 72 (Alphen aan den Rijn: Kluwer Law International, 2010). See more specifically, Wouter PJ Wils, "Principle of ne bis in idem in EC antitrust enforcement: A legal and economic analysis", World Competition 26, no. 2 (2003): 131-148.

${ }^{40}$ According to Marine Harvest, this principle implies that where one act appears to be caught by two statutory provisions, the primarily applicable provision excludes all others on the basis of the principles of subsidiarity, see paragraph 345 .
} 
this principle is limited to sequential proceedings and does not apply to situations in which two penalties are imposed for the same conduct in a single decision. ${ }^{41}$ The Court agreed that the framework of Articles 4(1) and 7(1) is unusual since the infringement of the first article necessarily entails infringement of the second one. However, the two separate fines are imposed for breaches of two different legal provisions. ${ }^{42}$ It is odd to see the existence of two infringements being punishable with fines of the same scale ${ }^{43}$ in a situation where one infringement necessarily entails the other. ${ }^{44}$ Therefore, the Court concluded that ne bis in idem did not apply in this case.

This case also addressed the concept of single concentration linked to the scope of the standstill obligation; the exemption in Article 7(2) and the latter's interactions with Article 7(3). Contrary to Marine's argument, the Court found that the acquisition in December 2012 and the subsequent public offer were not different steps in a single concentration. ${ }^{45}$ In particular, in order for a single concentration to exist, control must be acquired by means of several legal transactions. This was not the case with regard to Marine's acquisition of Morpol, in which control was acquired by means of the acquisition in December 2012 only. ${ }^{46}$ The EC statement that Article 7(2), which contains a derogation to Article 7(1) for public bids and acquisitions of securities where control is acquired from several sellers so-called "creeping bids" was maintained by the Court since it did not apply to this

\footnotetext{
${ }^{41}$ Judgment of 26 October 2017, Marine Harvest ASA v. EC, T-704/14, EU:T:2017:753, paragraphs 307-344.

${ }^{42}$ In other words, when an undertaking infringes the notification requirement in Article 4(1), an infringement of the standstill obligation in Article 7(1) is triggered automatically, paragraph 302. This is because the conduct giving rise to the two infringements, the closing of a transaction before notification, is one and the same, paragraph 305. See also Frederic Depoortere and Stephane Lalart. "Standstill Obligation in the ECMR" World Competition 33, no. 1 (2010): 103.

${ }^{43}$ Article 14(2)(a)(b) expressly sets out penalties up to $10 \%$ of the yearly turnover of undertakings when they "(a) fail to notify a concentration".

${ }^{44}$ Judgment of 26 October 2017, Marine Harvest ASA v. EC, T-704/14, EU:T:2017:753, paragraph 306. ${ }^{45}$ See Section 1.5.2 of the EC Consolidated Jurisdictional Notice under Council Regulation (EC) No 139/2004 on the control of concentrations between undertakings (2008/C 95/01). See also, Alison Jones \& Brenda Sufrin, EU Competition Law, Text, Cases, and Materials (Oxford: Oxford University Press, 2016), 1126.

${ }^{46}$ Judgment of 26 October 2017, Marine Harvest ASA v. EC, T-704/14, EU:T:2017:753, paragraph109. For the same reason, the General Court considered irrelevant that the public bid launched by Marine was triggered by the closing of the December 2012 Acquisition, see paragraphs 110-114; 148-152.
} 
case. The acquisition of December 2012 was simply a single private transaction involving only one seller. ${ }^{47}$

Another important issue was the application of regulation on limitation periods, ${ }^{48}$ in which the Court upheld the EC decision and provided a clarification. In addition, infringements of Article 4(1) and Article 7(1) were subject to different limitation periods -3 and 5 years, respectively - as explained in the case of Electrabel above. Keeping this in mind, the General Court stated that if the infringement of Article 4(1) were to include the infringement of Article 7(1), then an undertaking that were to implement a merger before notification and clearance would have an advantage vis-àvis an undertaking that were to implement a merger between notification and clearance. Given that this would have been an "absurd outcome", the Court concluded that EC was right in imposing on Marine fines for both infringements. ${ }^{49}$

Finally, when the principle of equal treatment was discussed by comparison with an undertaking that was not fined for the same type of conduct in a previous decision, the Court was not willing to accept it. The judges held that this principle had been properly relied on only by operators who had not had an opportunity to take into consideration the clarification provided in that previous decision in order to prevent infringements of the competition rules, since that decision was adopted when the infringement had already been committed. ${ }^{50}$

\subsection{Altice: in coherence between National and European Competition Authority}

The case of Altice is discussed from the perspective of two competition authorities -the FCA and the EC - as the second followed the decision of the first.

\footnotetext{
${ }^{47}$ Judgment of 26 October 2017, Marine Harvest ASA v. EC, T-704/14, EU:T:2017:753, paragraphs $71,75,76$.

${ }^{48}$ Regulation (EEC) No 2988/74 of the Council of 26 November 1974 concerning limitations periods in proceedings and the enforcement of sanctions under the rules of EEC related to transport and Competition.

${ }^{49}$ Judgment of 26 October 2017, Marine Harvest ASA v. EC, T-704/14, EU:T:2017:753, paragraph 353.

${ }^{50}$ Judgment of 26 October 2017, Marine Harvest ASA v. EC, T-704/14, EU:T:2017:753, paragraph 407, See Commission Decision, Case COMP/M.4730 - Yara/KemiraGrowHow.
} 


\subsubsection{The French Competition Authority (FCA)}

The decision of the FCA to impose a fine in the amount of $€ 80$ million represents a dramatic increase (around 400\%) of fines when compared to the last COM decisions discussed above. ${ }^{51}$

On 9 December 2014, Altice announced that it had signed an agreement to purchase its rivals SFR and OTL in France. Altice, operating in France through its subsidiary Numéricable, notified two concentrations to the FCA: the acquisition of the SFR group - the second French telecom operator - and the acquisition of the OTL group, a virtual mobile phone operator, functioning under the Virgin Mobile brand. Since the transaction met the threshold set by the French Commercial Code (Code) mirroring the EUMR, ${ }^{52}$ Altice was required to notify and obtain clearance before implementing it. Under the Code, gun-jumping infringements can be fined up to $5 \%$ on the total turnover of one year. ${ }^{53}$ The FCA cleared the two concentrations subject to commitments. Subsequently, the Authority addressed important practices as to how the undertaking restricted the competition in the market while constituting gun-jumping. Three features were underlined: the restrictions based on the contractual conditions, the amount of shared information, and the future operational integration. It is clear that while the parties are preparing themselves for a concentration, they need to meet. However, this communication should be conducted with due diligence assessments identifying the synergies. ${ }^{54}$ This should occur within specified boundaries, in as much as the parties continue to act independently in the market until approval is obtained. The teams partaking in the communication process should be external and anonymous. ${ }^{55}$ In this decision, for the first time the notion of "clean teams"

\footnotetext{
${ }^{51}$ Isabelle de Silva, the President of the FCA stated that the exchange of sensitive information is the key aspect, which must be taken into consideration during the evaluations of the concentrations. Although the exchange of information per se is not a cause for imposing a fine for Gun-Jumping, she underlined that it is strictly prohibited that they act as a single unit before the approval has been given. The president of FCA clearly specified that the shared information between the undertakings were highly strategic, very recent, and very detailed about all business and strategic matters. Isabelle de Silva, President of French Autorité de la Concurrence, "An interview about a historic gun-jumping case in the country", November 2017, https://www.womenat.com/w-at-competition. ${ }^{52}$ French Commercial Code, Article L430-3 and L430-4. See also Hugues Calvet and Olivier Billard, "France", The Merger Control Review, $7^{\text {th }}$ edition (2016): 189.

${ }^{53}$ French Commercial Code, Article L430-3 and L430-4 Ibid, paragraphs I and II.

${ }^{54}$ Décision no. 16-D-24 du 8 novembre 2016 relative à la situation du groupe Altice au regard du II de l'article L. 430-8 du code de commerce, paragraph 260.

${ }^{55}$ Ibid., paragraphs 260 and 318 .
} 
was discussed and considered empowering individuals not involved in the concentrated parties. ${ }^{56}$ Specific guidance on how the clean teams should operate is an important part of this decision, suggesting that these panels should be composed of external advisers only. The FCA took a very pragmatic approach. While focusing on the SPA, ${ }^{57}$ it also addressed the issue from a practical point of view. The FCA concluded that the parties had violated the rules on exchanging information regarding their offers, ongoing tenders, future plans regarding prices and marketing strategies, sharing the list of the consumers and their data, etc. The FCA decision also addressed the Memorandum of Understanding (MoU) signed by Altice and SFR, a provision of which stated that Altice could review the purchase price if the indicators showed the differences between the budget and the expenditures at the time of closing the transaction. The parties admitted that Altice was allowed to approve a series of investments and expenditures, interfering with SFR strategic and commercial decisions participating together in a tender and in the process of signing different cooperation agreements with their competitors. All of these and other non-permitted actions were done before obtaining clearance. Regarding the OTL, or the second undertaking, the FCA noted that based on the MoU, Altice was controlling the expenditures as well. They prohibited OTL from opening new branches or closing important contracts with other operators in the market. ${ }^{58}$ The FCA concluded that Altice interpreted the provisions of the $\mathrm{MoU}$ with the "language of control" in different circumstances such as sharing of the information, joint purchasing, preparation of operational integration, etc. ${ }^{59}$ The authority established that the project between Altice and SFR marked a turning point in the whole strategy of SFR, forced by the acquirer. ${ }^{60}$ The FCA suggestion was that the merging parties could impose general obligations on the target undertaking only if they were

\footnotetext{
56 "The term clean team refers to a restricted group of individuals from the business that are not involved in the day-to-day commercial operation of the business who receive confidential information from the counter party to the transaction and are bound by strict confidentiality protocols with regard to that information". Comission Decision of 24 April 2018 addressed to Altice N.V. imposing a fine for putting into effect a concentration in breach of Article 4(1) and Article 7(1) of Council Regulation (EC) No. 139/2004 (Case M.7499, Altice/PT Portugal, Article 14(2) procedure), paragraph 53, footnote 35 .

${ }^{57}$ Share Purchase Agreement (SPA).

${ }^{58}$ Décision no. 16-D-24 du 8 novembre 2016 relative à la situation du groupe Altice au regard du II de l'article L. 430-8 du code de commerce, paragraphs 200-204.

${ }^{59} \mathrm{Ibid}$., paragraphs $259-260$.

${ }^{60} \mathrm{Ibid}$., paragraphs 113-117.
} 
necessary and proportionate to protect the consumers' interests until and if the green light were given. Altice intervenes in commercial policies such as pricing policies and in the definition of SFR's commercial policy, i.e. tariffs for a high-speed offer. The parties globally reinforced their commercial relations and co-managed an important project concerning very high speed wholesale offers. In the OTL transaction, key managers were prematurely appointed and started acting in their new position before the closing. Seen globally, the parties frequently exchanged key and sensitive information, for instance during regularly organised pre-integration meetings. It is important to underline that the FCA insisted on the fact that these infringements should not be given as a "checklist" to interested stakeholders. According to the authority, the key element in this decision which accounted for a very high fine was the fact that the parties showed an overall and complete unawareness of the rules related to gun-jumping and behaved, in all aspects, as if they were a single undertaking. Ultimately, in November 2016, the FCA imposed an unprecedented $€ 80$ million fine in the telecom sector for merger control gun-jumping in the takeover of SFR by Altice.$^{61}$ It was established that the parties had cooperated too closely, a common feature for the two acquisitions mentioned above. This Decision was considered very useful in providing guidance as to what the parties are (and are not) allowed to take into account before deciding to merge. ${ }^{62}$

\subsubsection{An EU perspective: opening the door for different aspects of Gun-jumping}

Following the FCA decision, on April 2018, the EC imposed a fine of $€ 124.5$ million on Altice for partially implementing the acquisition of its Portuguese competitor PT Portugal before EC approval. In this case, the EC, following a similar legal agenda based on the violation of Articles 4(1) and 7(1) deliberated by FCA, underlined that gun-jumping can take new and diverse forms such as the exchange of key and sensitive information discussed in FCA-Altice. In addition, it made a clear distinction between the possibility of exercising decisive influence and the actual exercise of

\footnotetext{
${ }^{61}$ Décision no. 16-D-24 du 8 novembre 2016 relative à la situation du groupe Altice au regard du II de l'article L. 430-8 du code de commerce, paragraphs 303-307.

${ }^{62}$ Commission Decision of 24 April 2018, imposing a fine for putting into effect a concentration in breach of Article 4(1) and Article 7(1) of Council Regulation (EC) No. 139/2004 (Case M.7993 Altice/PT Portugal, Article 14(2) Procedure).
} 
decisive influence. ${ }^{63}$ In other words, early implementation of a concentration in breach of Article 4(1) and/or Article 7(1) EUMR can arise in different forms, and the acquisition of the possibility of exercising decisive influence and/or the actual exercise of decisive influence by the acquiring undertaking over the target prior to notification and/or clearance of the transaction is only one of those potential forms of early implementation. ${ }^{64}$

As to the facts, the EC's Altice decision arose out of Altice's acquisition of PT Portugal from Brazilian telecom operator Oi, which was approved by the EC in 2015, subject to divestment. In 2017, the EC raised concerns that Altice may have partially implemented its acquisition of PT Portugal prior to the EC's approval decision and, in some instances, even prior to the notification. Based on the EC decision, the conduct during the "greyzone" ${ }^{65}$ which is the period between the signing and closing, was abusive Linked to the SPA, the EC emphasised that an authorisation by Altice was crucial in order to carry out the activities in Oi's ordinary course of business. ${ }^{66}$ The decision also stated that the interaction between the two parties was quite frequent. In particular, the rule of gun-jumping was violated under the SPA by the influence Altice exercised over PT Portugal and the exchange of granular sensitive information between them. ${ }^{67}$ It was explained that control means the possibility of exercising decisive influence over the target on a de jure or de facto basis. ${ }^{68}$ The EC therefore concluded that, based on the SPA, Altice had the right to exercise decisive influence over PT Portugal before notification and approval. Altice possessed veto rights ${ }^{69}$ over the appointment and termination of PT Portugal's directors and other executives, pricing policies and commercial terms and conditions with costumers, decisions to enter or terminate or modify certain

\footnotetext{
${ }^{63}$ Ibid., paragraph 42.

${ }^{64} \mathrm{Ibid}$., see footnote 34 .

${ }^{65}$ The term Grey-zone indicates the interim period, which considers the time between the signing and closing the transaction. The principle was raised in the Commission's Decision Com. Dec M. 7993 - Altice/PT Portugal, 50.

${ }^{66}$ Commission Decision of 24 April 2018, imposing a fine for putting into effect a concentration in breach of Article 4(1) and Article 7(1) of Council Regulation (EC) No. 139/2004 (Case M.7993 Altice/PT Portugal, Article 14(2) Procedure), paragraph 121.

${ }^{67}$ Ibid., paragraphs 49-53.

${ }^{68} \mathrm{Ibid}$., paragraph 43. See also, EC Consolidated Jurisdictional Notice under Council Regulation (EC) No. 139/2004 on the control of concentrations between undertakings (2008/C 95/01), paragraph 16. Check, as well, Richard Whish and David Bailey, Competition Law, $9^{\text {th }}$ edition (Oxford: Oxford University Press, 2018), 854.

${ }^{69}$ Ibid., paragraph 76 .
} 
contracts, etc. Another slightly different approach toward the notion of "clean teams" defined broadly in the FCA decision was that the EC took a narrower view. ${ }^{70}$

Conclusively, it was established that Altice was actively involved in the decision-making processes at PT Portugal concerning marketing campaigns, negotiation of strategies and terms of commercial contracts, future investments, etc.

\subsection{Ernst and Young: a thin line between Article 7(1) EUMR and Article 101 TFEU}

Compared to the cases discussed above dealt by National Courts and/or the EC such as Altice (on exchange of detailed information exchange), or cases such as Marine Harvest and Electrabel (failure to file), Ernst and Young ${ }^{71}$ comes under a specific category of gun-jumping, that of partial or earlier implementation based on very unique facts. ${ }^{72}$ This is the first preliminary ruling in which the ECJ defined the much-debated notion of "standstill obligation". It was ruled out that an unlawful implementation of a concentration in violation of the standstill obligation can only arise when a measure contributes to the change of control of the targeted undertaking on a lasting basis.

As to the facts, on 18 November 2013, KPMG Denmark (DK) and Ernst and Young, both dealing with auditing activities in Denmark, decided to merge. During this period, KPMG DK were members of KPMG International, based on an exclusive cooperation agreement (ECA). ECA contained provisions on the allocations of customers, the obligation to service clients, and provided that the participating firms could not conclude contracts such as partnerships or joint ventures. KPMG DK announced the termination of this agreement to take place within at least 6 months' notice before the end of KPMG International's year, which was one of the conditions of the merging parties. The following step was the notification, based on which the Danish Competition Authority (DCA) cleared the merger.

\footnotetext{
${ }^{70}$ See footnote 56

${ }^{71}$ Judgment of 31 May 2018, Ernst \& Young P/S v. Konkurrencerådet, C-633/16, EU:C:2018:23.

${ }^{72}$ James Webber (Sherman \& Sterling), "Gun-jumping: Practical implications of recent case law", Workshop organized by Concurrences Review, in partnership with Shearman \& Sterling and Avisa. Uploaded on 15 October 2018, https://vimeo.com/295163258. See also Massimiliano Kadar and Jean-Christophe Mauger, "Harvesting salmon, jumping guns: The Marine Harvest early implementation case", Competition Merger Brief 1/2004, available at www. ec.europa.eu/competition/publications/cpn.
} 
Corresponding to the $\mathrm{EUMR}^{73}$, the Danish $\mathrm{Law}^{74}$ prohibits the parties to take further steps in implementing their mergers before clearance is provided. This authority issued an additional decision, declaring that KPMG DK had breached the standstill obligation by terminating the cooperation agreement with KPMG International after the notification was made and prior to getting the approval. Based on the DCA, the termination of the cooperation agreement was merger-specific, irrevocable and may influence the market effect during the "interim period". Despite that the termination only took effect 6 months after giving the notice and receiving the approval, costumers switched from KPMG DK to KPMG International. In order to determine whether the earlier and partial implementation was considered a breach of the standstill obligation, a clear definition of the meaning and the scope of the notion were required. Based on the Ernst \& Young appeal to annul the contested Decision, the Danish Maritime and Commercial Court referred the questions for preliminary ruling to the ECJ, enquiring, among other questions, what the standstill obligation concept encompassed and whether the termination of the cooperation agreement produced any market effect.

The judgment on a request for a preliminary ruling was handed down on 31 May 2018 concerning the scope of the standstill obligation in relation to the early termination of the cooperation agreement. It stated that regardless of whether the termination of its exclusive cooperation agreement had produced market effects, it may not be regarded as bringing about the implementation of concentration as such. ${ }^{75}$ In regard to the crucial issue on the demarcation of the standstill obligation concept, both the EC and the Danish Government suggested a broad definition of the notion. In particular, the Danish Government emphasised that internal preparatory steps ought to be excluded from the scope of a standstill obligation; however, a broad definition would benefit all stakeholders. ${ }^{76}$ Another proposal worth mentioning was the negative definition of gun-jumping suggested by Advocate General (AG) Wahl. According to the AG, a negative delineation should be considered, more than a positive one. In other

\footnotetext{
${ }^{73}$ Council Regulation (EC) No. 139/2004 of 20 January 2004 on the control of concentrations between undertakings (the EC Merger Regulation), OJ L 24/1, 29 January 2004.

${ }^{74}$ Lovbekendtgorelse nr. 869 af 8. Juli 2015, Lovtidende 2015 A.

${ }^{75}$ Judgment of 31 May 2018, Ernst \& Young P/S v. Konkurrencerådet, C-633/16, EU:C:2018:23, paragraph 60.

${ }^{76}$ Opinion of Advocate General Nils Wahl of 18 January 2018, Ernst \& Young P/S v. Konkurrencerådet, C-633/16, EU:C:2018:23, paragraph 41.
} 
words, it would be desirable for the Court to provide an explanation of the measures not to be caught by a standstill obligation, and not the other way around. ${ }^{77}$ The Court followed the pragmatic view provided by the AG that the main criterion to be followed was the teleological interpretation of "concentrations" established under EUMR. ${ }^{78}$ The "control", defined in Article 3(2) EUMR, in conjunction with the jurisdictional notice, must be prioritised ${ }^{79}$ and, to ensure effective control, undertakings are obliged to provide prior notification of concentrations with a community dimension following the conclusion of the agreement. ${ }^{80} \mathrm{He}$ stressed that a concentration shall be deemed to arise where a change of control on a lasting basis results from the acquisition by one or more persons already controlling at least one undertaking. ${ }^{81}$ The Court explicitly stated that Ernst \& Young did not use any kind of control such as prices, shares or detailed planning and made no pressure what so ever for KPMG to terminate the agreement with KPMG International. ${ }^{82}$ Based on the fact that in this case the transaction concerned only one of the merging parties in correlation with a third party, Ernst \& Young stayed outside the domain of exercising control..$^{83}$ The Court specified that Article 7(1) must be based on the shift of control. Shift of control entails the power of exerting decisive influence, which was not seen in this case. The fact that KMPG individually decided to terminate the agreement proved that they were in a position to make decisions independently. Finally, the Court ruled that an unlawful implementation of a concentration in violation of the standstill obligation can only arise

\footnotetext{
${ }^{77} \mathrm{Ibid}$., paragraphs 44-45. The AG also advised the Court to review the prescribed fines in the previous decisions on Gun-jumping. He underlined that it is highly important for the Court in this ruling to take into consideration the imposed fines on Gun-jumping so far, both from National Competition Authorities and the EC, see paragraph 43.

${ }^{78}$ Ibid., paragraphs 44-49.

${ }^{79}$ EC Consolidated Jurisdictional Notice under Council Regulation (EC) No 139/2004 on the control of concentrations between undertakings (2008/C 95/01). See also Philipp Werner, Serge Clerckx, and Henry de la Barre. "Commission expansionism in EU merger control - Fact and fiction”. Journal of European Competition Law \& Practice 9, no. 3 (2018): 133-145.

${ }^{80}$ This was also required by Ernst \& Young referring to Aer Lingus when they provided their arguments. See Recital 20 and paragraphs 62 and 65 of the Case: T-411/07, EU:T:2010:281.

${ }^{81}$ EUMR, Article 3(1)(b) EUMR. It must be ensured that the process of reorganization does not result in lasting damage to competition see Recital 5, and article 3(1)(b).

${ }^{82}$ Judgment of 31 May 2018, Ernst \& Young P/S v. Konkurrencerådet, C-633/16, EU:C:2018:23, paragraphs 12-13.

${ }^{83} \mathrm{Ibid}$., paragraph 61.
} 
when a measure "in whole or in part, in fact or in law contributes to the change of control". However, this was not the case in Ernest \& Young. ${ }^{84}$

Observing the standstill obligation, the Court underlined what the EC stated in Altice, that both gun-jumping and standstill obligations are very important instruments for the EC's effective control of mergers. ${ }^{85}$ If undertakings jump the gun and do not notify on time, or notify partly, or they exchange their detailed and sensitive information, the EC will not be able to exercise effective and successful control. ${ }^{86}$ The pragmatic approach of the judges and the way the complex construction was simplified without prior precedents awaken the response that mergers must be treated strictly based on the EUMR in order for Article 101 TFEU not to be affected. ${ }^{87}$ Otherwise, the Court considers it an incursion of Article 101 TFEU if the standstill obligation notion is defined broadly. ${ }^{88}$ Instead, the limited demarcation of the standstill obligation in this ruling instills that if the focus is only on the lasting change of control, it will not provide sufficient clarifications on such a complex notion of competition law. Although undertakings must continue to act with caution, legal certainty should not be compromised.

\section{Between EC discretional powers and the scarcity of finning guidelines}

Based on the above-mentioned decisions and judgments, it is more than clear that Article 14(3) needs normative establishment, to say the least, by adopting soft law (such as guidelines) to avoid a legal vacuum. ${ }^{89}$ Article 14(3) EUMR is broad and ambiguous, and in particular the factors enumerated in it must be articulated specifically. ${ }^{90}$ Fines should be imposed in

\footnotetext{
${ }^{84}$ Ibid., paragraph 59.

${ }^{85} \mathrm{Ibid}$., paragraph 50.

${ }^{86}$ Commission Decision of 24 April 2018, imposing a fine for putting into effect a concentration in breach of Article 4(1) and Article 7(1) of Council Regulation (EC) No. 139/2004 (Case M.7993 Altice/PT Portugal, Article 14(2) Procedure), paragraphs 455 and 468-471, See also Pierre Honoré, and Guillaume Vatin. "The French competition authority's Altice decision: Record fine for the first 'genuine' gun-jumping case in Europe". Journal of European Competition Law and Practice 8,5 (2017).

${ }^{87}$ Judgment of 31 May 2018, Ernst \& Young P/S v. Konkurrencerådet, C-633/16, EU:C:2018:23, paragraph 57.

${ }^{88} \mathrm{Ibid}$., paragraph 58 and Advocate General opinion, paragraph 68.

${ }^{89}$ The guidelines will also provide guidance to the NCAs. See more on the purpose of finning guidelines, Wouter PJ Wils, "European Commission's 2006 guidelines on antitrust fines: A legal and economic analysis". World Competition 30, no. 2 (2007): 197.

${ }^{90}$ Ivo Van Bael, "Fining a la carte: The lottery of EU competition law", European Competition Law Review 16, no. 4 (1995): 237-243.
} 
accordance with the specific nature, gravity and duration of the infringement. The development of EEC competition policy followed a top-down approach with the European Commission designing and enforcing it at the same time..$^{91}$ Therefore, this institution should further shape the substantive competition law on fines and fining. ${ }^{92}$

As addressed initially in the Facebook case, the EC indicated that both infringements were serious by nature, but noted that they did not have any impact on the outcome of the decision approving the transaction. However, a mitigating factor was taken into consideration to make the EC reduce the fine based on the cooperation the undertaking offered. However, the cooperation principle was not accepted in the case of Marine or Altice. In Marine, several mitigating circumstances were excluded, such as the cooperation during the merger control procedure, which according to the Court were not applicable to infringements of Articles 4(1) and 7(1) of EUMR. These circumstances would more likely apply in cases of obstructions, such as Facebook/ Whatsapp, the EC explained. ${ }^{93}$ In Altice, the EC stated that the undertaking had replied to the request for information to exercise its right of defense, by submitting documents, but had not actively assisted the authority in establishing the infringement, based on which Altice's cooperation was not considered a mitigating factor. ${ }^{94}$

Since there was no exhaustive list of factors to assess the gravity of the infringement in Marine, the Court took into consideration the history of the case, in particular the fact that Marine had previously been fined at national level for a similar infringement, ${ }^{95}$ which could have been used as an aggravating factor, although it was not. The Court implicitly noted that

\footnotetext{
${ }^{91}$ Piet Jan Slot and Matin Farley, An Introduction to Competition Law (Bloomsbury Publishing, 2017), 316.

${ }^{92}$ Pablo Ibañez Colomo, The Shaping of EU Competition Law (Cambridge: Cambridge University Press, 2018), 328.

${ }^{93}$ Judgment of 26 October 2017, Marine Harvest ASA v. EC, T-704/14, EU:T:2017:753, paragraph 634.

${ }^{94}$ Commission Decision of 24 April 2018, imposing a fine for putting into effect a concentration in breach of Article 4(1) and Article 7(1) of Council Regulation (EC) No. 139/2004 (Case M.7993 Altice/PT Portugal, Article 14(2) Procedure), paragraph 604. This is another moment proving that although the mitigating factors are not included in any written norm related to mergers, the EC reflected the standard of culpability applicable to fines for procedural infringements in the fields of article 101 and 102 TFEU. See also Luis Ortiz Blanco and Andrew Read (eds.), EU Competition Procedure. Oxford University Press, 2013.

${ }^{95}$ Judgment of 26 October 2017, Marine Harvest ASA v. EC, T-704/14, EU:T:2017:753, paragraphs 465-466, 469, 482 and 536-539.
} 
the EC had refrained from considering Marine's gun-jumping at EU level as a repeated offence at national level. ${ }^{96}$ The judges also noted that the EC took into account "mitigating factors such as the applicant having acted negligently rather than intentionally" and the fact that the applicant had "sought legal advice". ${ }^{97}$ It was stated that the EC is allowed to consider the fact that a transaction gives rise to serious doubts as to its compatibility with the internal market amongst the factors rendering the infringement more serious. ${ }^{98}$ The Court agreed with the EC's decision to consider that the whole period of pre-notification and examination of the concentration was to be taken into account for the purposes of establishing the duration of the infringement of Article 7(1). ${ }^{99}$

Electrabel, on the other hand, is a case that, although the transaction was implemented earlier, was cleared without remedies since it raised no competition concerns. On the question of mitigating circumstances, the EC noted that Electrabel voluntarily answered all of the EC's questions. The high fine was imposed despite the fact that the undertaking's infringement was unintentional in nature.$^{100}$ One may conclude that this fine sends a clear message to third parties that a new sanctioning gate is re-triggered having deterrent effects. ${ }^{101}$ The above-mentioned arrangement also has an impact on the duration of the infringement as another important factor, as intermediate cases will not benefit from the EC's discretion in less serious cases to exclude the pre-notification phase from the infringement period as a reward for an undertaking's cooperation with the EC during the procedure. ${ }^{102}$

Marine argued that the absence of straightforward precedent providing a clear interpretation of Article 7(2) EUMR was excluded on the grounds that the absence of precedent ought to be assessed with respect to Article 14(2) of EUMR, applied in several occasions. ${ }^{103}$ However, in light of this

\footnotetext{
${ }^{96}$ Ibid., paragraphs 533-534 and 539.

${ }^{97}$ Ibid., paragraph 607.

${ }^{98} \mathrm{Ibid}$., paragraphs $483-528$.

${ }^{99} \mathrm{Ibid}$., paragraphs 552-578.

${ }^{100}$ Ariel Ezrachi, EU Competition Law: An Analytical Guide to the Leading Cases (Bloomsbury Publishing, 2018), 438.

${ }^{101}$ Judgment of 3 July 2014, Electabel v. EC, C-84/13 P, EU:C:2014:2040, paragraph 226. See also Dorte Hoeg, European Merger Remedies: Law and Policy (Bloomsbury Publishing, 2014).

${ }^{102} \mathrm{Ibid}$., paragraphs 566 and 572-573.

${ }^{103}$ Judgment of 26 October 2017, Marine Harvest ASA v. EC, T-704/14, EU:T:2017:753, paragraphs 640-642.
} 
limited interpretation, undertakings are thus prevented from raising the absence of clear precedent as a mitigating circumstance in merger cases in the future, the Court ruled. Concerning Article 7(1) EUMR, Altice brought a complaint that in absence of precedent linked to this paragraph, undertakings cannot assess the scope of their obligations before closing, therefore their conduct should be considered as less serious than a violation of Articles 101 or 102 TFEU. Furthermore, the infringements of Article 7(1) EUMR should be considered less serious if the merger is ultimately cleared by the EC compared to cases in which the merger is blocked. ${ }^{104}$ However, the EC established that any infringement of Article 4(1) and Article 7(1) of EUMR is by nature a serious infringement; therefore a maximum fine should be imposed. ${ }^{105}$ Altice tried to argue that the infringements of Articles 4(1) and 7(1) EUMR should not entail the same degree of gravity compared to Articles 101 and 102 TFEU since within the mergers the acquirer will gain some control over the target at some point and competitors cannot remain completely independent as it is the case with the first pillar. Therefore, the undertaking asked for a symbolic fine to be imposed considering in particular the situation of non-transparency and legal uncertainty faced by them at the time of the infringements. ${ }^{106}$

\section{Conclusion}

Although lacking detailed legal basis, the imposition of fines for infringements of procedural matters within EU mergers has evolved from symbolic penalties to substantive sums amounting to tens of millions of euros. Therefore, there is a strong argument to be made for the adoption of a more detailed law on fining methods for breach of procedural matters. This is what the General Court suggested in the case of Marine by stating that there are no applicable guidelines setting out the method of calculation fines for infringements of merger control rules, placing all the parties in a difficult situation. ${ }^{107}$ In the case of Altice, the undertaking argued that,

\footnotetext{
${ }^{104}$ Commission Decision of 24 April 2018, imposing a fine for putting into effect a concentration in breach of Article 4(1) and Article 7(1) of Council Regulation (EC) No. 139/2004 (Case M.7993 Altice/PT Portugal, Article 14(2) Procedure), paragraph 568.

${ }^{105}$ It must not be forgotten that the case of marine was fined $1 \%$ of their annual total turnout.

${ }^{106}$ Commission Decision of 24 April 2018, imposing a fine for putting into effect a concentration in breach of Article 4(1) and Article 7(1) of Council Regulation (EC) No. 139/2004 (Case M.7993 Altice/PT Portugal, Article 14(2) Procedure), paragraph 605.

${ }^{107}$ Judgment of 26 October 2017, Marine Harvest ASA v. EC, T-704/14, EU:T:2017:753, paragraph 455.
} 
if the EC was to impose a fine, it should be of a symbolic amount having in mind the legal requirement for legal uncertainty. Altice explicitly pointed out that there are no guidelines available regarding the calculation of fines for violations of Articles 4(1) and 7(1) EUMR, therefore the lack of transparency constitutes a serious breach of the principle of legal expectation. Due to the fact that there is also a lack of "precedent" in fining the undertakings during the interim period in particular, undertakings are unable to properly assess the scope of their rights and obligations during the pre-closing period. The legal certainty principle must not be weakened by institutional actions. It is well known that in the absence of rules, standards may rise.

In the decisions discussed in this article, the EC has reflected upon the fining guidelines' principles based on Regulation 1/2003. However, one should note that this Regulation, and in particular the fining guidelines based on it, concern only Articles 101 and 102 TFEU and do not apply to mergers. ${ }^{108}$

The arguments related to repeated offences and the deterrent effect that fines may have, must also be in line with the effects those undertakings ultimately have in the market. ${ }^{109}$ The EC argues that the fines are imposed in order to prevent the undertakings from recurring to the same infringements. The second reason stated in all decisions mentioned above, is the need to ensure that fines have a sufficiently deterrent effect to third parties. These powers are guided by the general principles of EU Law applicable to administrative fines, particularly the principles of equal treatment and proportionality, and the need to ensure sufficient deterrent effect must be checked and balanced.

Therefore, the question stands: how far will the EC proceed with fining before deciding to issue adjustable guidelines? Since fines are considered an arm through which the EC flies haphazardly and arbitrarily, ${ }^{110}$ the

\footnotetext{
${ }^{108}$ Eric Barbier de La Serre and Eileen Lagathu, "The law on fines imposed in EU Competition proceedings: Faster, higher, harsher", Journal of European Competition Law \& Practice 4, no. 4 (2013): 326.

${ }^{109}$ Wouter PJ Wils, "EC competition fines: To deter or not to deter." Yearbook of European Law 15, no. 1 (1995): 17-46.

${ }^{110}$ It is proven than when mergers are under scrutiny, the direct jurisdiction through the EC plays the key role. Similar practice can be found in the US, where courts decide relatively few merger cases and therefore merger law is a prediction of what the Antitrust Agencies will do. Therefore the Agencies have huge discretion in formulating and enforcing the relevant norms. See more in Daniel Crane, Antitrust (Wolters Kluwer, Law \& Business, 2014) 145. For differences in the rhetoric
} 
discretional powers of this authority should be measured, ${ }^{111}$ and the only way to do so is by filling the legal vacuum and taking a more legalistic approach. ${ }^{112}$

\section{Bibliography}

Alexiadis, Peter, Elsa Sependa, and Laura Vlachos. "Merger control: 'Around the world in 80 days: Management of the merger review process of global deals"'. Business Law International 19, no. 3 (2018). 201-244.

Barbier de La Serre, Eric and Lagathu, Eileen. "The law on fines imposed in EU competition proceedings: Faster, higher, harsher". Journal of European Competition Law \& Practice 4, no. 4 (2013): 325-344.

Barbier de La Serre, Eric and Lagathu, Eileen. "The law on fines imposed in EU competition proceedings: Fifty shades of undertakings". Journal of Competition Law \& Practice 6, no. 7 (2015): 530-552.

Blanco, Luis Ortiz and Andrew Read (eds.). EU Competition Procedure. Oxford: Oxford University Press, 2013.

Calvet, Hugues and Olivier Billard. "France". The Merger Control Review, $7^{\text {th }}$ edition, 2016.

Colomo, Pablo Ibañez. The Shaping of EU Competition Law. Cambridge: Cambridge University Press, 2018.

Crane, Daniel, Antitrust. Alphen aan den Rijn: Wolters Kluwer, Law \& Business, 2014.

De Silva, Isabelle, "An interview about a historic gun-jumping case in the country".

November 2017. https://www.womenat.com/w-at- competition.

between EU and US antitrust see also Eleanor M. Fox and Damien Geradin, EU Competition Law: Cases, Text and Context (Elgar Publishing, 2017), 7-8.

${ }^{111}$ The wide discretional powers of the EC and the limited scope of Judicial Review has been long debated within the first two pillars, see in this context, Rita Leandro Vasconcelos, "Commitment decisions: Is the sky the limit? Commentary to judgment of the General Court (Eighth Chamber) of 15 September 2016, T-76/14, Morningstar, Inc. v. European Commission", Market and Competition Law Review 1, no. 2 (2017): 195-212.

${ }^{112}$ Ioannis Lianos, "Competition law remedies in Europe: Which limits for remedial discretion?" (2013). However, it is true that the fining guidelines will not solve the whole problem. The other true remains also that the EC discretional powers cannot totally be limited see more: Wouter PJ Wils, "Discretion and prioritisation in public antitrust enforcement, in particular EU antitrust enforcement." World Competition 34, no. 3 (2011): 353-382. On the other hand, the unlimited judicial review in the hand of judges to address these issues can rightfully prompt the EC to develop basic guidelines. Eric Barbier de La Serre and Eileen Lagathu, "The law on fines imposed in EU competition proceedings: Fifty shades of undertakings", Journal of Competition Law \& Practice 6, no. 7 (2015): 549. 
Depoortere, Frederic and Stephane Lalart. "The standstill obligation in the ECMR". World Competition 33, no. 1 (2010): 103-120.

Drago, Bruno de Luca and Fabianna Vieira Barbosa Morselli. "Clarifying gun-jumping through guidelines: The Brazilian experience". Journal of European Competition Law \& Practice 7, no. 2 (2016): 130-134.

Ezrachi, Ariel. EU Competition Law: An Analytical Guide to the Leading Cases. Bloomsbury Publishing, 2018.

Fox, Eleanor M. and Damien Geradin: Cases, Text and Context. Elgar Publishing, 2017. Geradin, Damien and Katarzyna Sadrak. "The EU competition law fining system: A quantitative review of the Commission Decisions between 2000 and 2017", TILEC discussion paper, http://ssrn.com/abstract=2887628 2017.

Gomes, Emanuel, Duncan N. Angwin, Yaakov Weber, and Shlomo Yedidia Tarba. "Critical success factors through the mergers and acquisitions process: Revealing preand post-M\&A connections for improved performance". Thunderbird International Business Review 55, no. 1 (2013): 13-35.

Gotts, Ilene Knable. The Merger Review Process: A Step-by-Step Guide to US and Foreign Merger Review. United States of America: ABA Publishing, 2006.

Hoeg, Dorte. European Merger Remedies: Law and Policy. Bloomsbury Publishing, 2014. Howson, Peter. Due diligence: The Critical Stage in Mergers and Acquisitions. Routledge, 2017.

Jones, Alison, and Brenda Sufrin. EU Competition Law, Text, Cases, and Materials. Oxford: Oxford University Press, 2016.

Kadar, Massimiliano and Jean Christophe Mauger, "Harvesting salmon, jumping guns: The Marine Harvest early implementation case". Competition Merger Brief 1/2004, available at www. ec.europa.eu/competition/publications/cpn.

Kokkoris, Ioannis and Howard Shelanski. EU Merger Control: A Legal and Economic Analysis. Oxford: Oxford University Press, 2014.

Lianos, Ioannis. "Competition Law Remedies in Europe: Which Limits for Remedial Discretion?”, CLES Research Paper 2 (2013).

Marty, Frederic \& Medhi Mezaguer. "Negotiated procedures in EU competition law". In Encyclopedia of Law and Economics, edited by Alain Marcino, Giovanni Battista Ramello. New York: Springer, 2018.

Morse, M. Howard. "Mergers and acquisitions: Antitrust limitations on conduct before closing." The Business Lawyer 57, no. 4 (2002): 1463-1486.

Honoré, Pierre and Guillaume Vatin. "The French competition authority's Altice decision: Record fine for the first 'genuine' gun-jumping case in Europe". Journal of European Competition Law \& Practice 8, no. 5 (2017): 314-320. 
Slot, Piet Jan and Matin Farley. An Introduction to Competition Law. Bloomsbury Publishing, 2017.

Van Bael, Ivo. "Fining a la carte: The lottery of EU competition law". European Competition Law Review 16, no. 4 (1995). 237-243.

Van Bockel, Bas. The Ne Bis in Idem Principle in EU Law. Vol. 72. Alphen aan den Rijn: Kluwer Law International, 2010.

Vasconcelos, Rita Leandro. "Commitment decisions: Is the sky the limit? Commentary to Judgement of the General Court (Eighth Chamber) of 15 September 2016, T-76/14, Morningstar, Inc. v. European Commission". Market and Competition Law Review 1, no. 2 (2017): 195-212.

Webber, James. "Gun-jumping: Practical implications of recent case law". Workshop organized by Concurrences Review, in partnership with Shearman \& Sterling and Avisa. Uploaded on 15 October 2018. https://vimeo.com/295163258.

Werner, Philipp, Serge Clerckx, and Henry de la Barre. "Commission expansionism in EU merger control - Fact and fiction". Journal of European Competition Law \& Practice 9, no. 3 (2018): 133-145.

Whish, Richard and David Bailey. Competition Law. $9^{\text {th }}$ edition. Oxford: Oxford University Press, 2018.

Wils, Wouter PJ. "Discretion and prioritisation in public antitrust enforcement, in particular EU antitrust enforcement”. World Competition 34, no. 3 (2011): 353-382.

Wils, Wouter PJ. "EC competition fines: To deter or not to deter". Yearbook of European Law 15, no. 1 (1995): 17-46.

Wils, Wouter PJ. “European Commission's 2006 guidelines on antitrust fines: A legal and economic analysis". World Competition 30, no. 2 (2007): 197-229.

Wils, Wouter PJ. "The principle of ne bis in idem in EC antitrust enforcement: A Legal and economic analysis". World Competition 26, no. 2 (2003): 131-148. 